\title{
Cumulative Vulnerability: A Case Study on Domestic Violence, Drug Addiction and Adolescent Pregnancy
}

\author{
VULNERABILIDADE CUMULATIVA: ESTUDO DE UM CASO DE VIOLÊNCIA DOMÉSTICA, \\ TOXICODEPENDÊNCIA E GRAVIDEZ NA ADOLESCÊNCIA
}

\author{
VULNERABILIDAD ACUMULADA: ESTUDIO DE UN CASO DE VIOLENCIA DOMÉSTICA, \\ DROGADICCIÓN Y EL EMBARAZO EN LA ADOLESCENCIA
}

\section{Paula Orchiucci Miura1', Gislaine Martins Ricardo Passarini ${ }^{2}$, Loraine Seixas Ferreira ${ }^{3}$, Rui Alexandre Paquete Paixão ${ }^{4}$, Leila Salomão de La Plata Cury Tardivo ${ }^{5}$, Dora Mariela Salcedo Barrientos ${ }^{6}$}

\begin{abstract}
A pregnant adolescent's vulnerability increases when she is a victim of domestic violence and drug addiction, which cause physical and biopsychosocial damage to the mother and her baby. Objective: Present and analyze the case of an adolescent who is addicted to drugs, pregnant and the victim of lifelong domestic violence. Method: A case study based on a semistructured interview conducted in the Obstetrics Emergency Unit at the Teaching Hospital of the University of São Paulo. The data were interpreted and analyzed using Content Analysis. Results: Domestic violence experienced at the beginning of the adolescent's early relationships seriously affected her emotional maturity, triggering the development of psychopathologies and leaving her more susceptible to the use and abuse of alcohol and other drugs. The adolescent is repeating her history with her daughter, reproducing the cycle of violence. Conclusion: Adolescent pregnancy combined with domestic violence and drug addiction and multiplies the adolescent's psychosocial vulnerability increased the adolescent's vulnerability.
\end{abstract}

\section{RESUMO}

A vulnerabilidade da adolescente grávida potencializa-se ao ser vítima de violência doméstica e toxicodependente, causando danos físicos e biopsicossociais para si e para o bebê. Objetivo: apresentar e analisar o caso de uma adolescente toxicodependente, grávida e vítima de violência doméstica ao longo da vida. Método: "estudo de caso" baseado numa entrevista semi-estruturada, realizada no Pronto Atendimento de Obstetrícia do Hospital Universitário da Universidade de São Paulo. Os dados foram interpretados e analisados segundo a Análise de Conteúdo. Resultados: a violência doméstica vivenciada no início das relações primordiais afetou gravemente $o$ amadurecimento emocional da adolescente, desencadeando o desenvolvimento de psicopatologias e ficando mais suscetível ao uso e abuso de álcool e outras drogas. A adolescente repete sua história com sua filha, reproduzindo o ciclo da violência. Conclusão: a gravidez na adolescência somada a violência doméstica e a toxicodependência potencializou a vulnerabilidade psicossocial da adolescente.

\section{DESCRIPTORS}

Adolescent pregnancy

Domestic violence

Drug addiction

\section{DESCRITORES}

Gravidez na adolescência

Violência doméstica

Toxicodependência

\section{RESUMEN}

La vulnerabilidad de la adolescente embarazada se acentúa mucho más cuando la misma es víctima de la violencia doméstica y es adicta a las drogas, provocando daño físico y biopsicosocial para ella y su bebé. Objetivo: presentar y analizar el caso de una adolescente adicta a las drogas, embarazada y víctima de violencia doméstica durante el transcurso de su vida. Método: Se trata de un estudio de caso, basado en una entrevista semi-estructurada, realizada en el Servicio de Emergencia de Obstetricia de un Hospital Universitario en la ciudad de Sao Paulo. Los datos fueron recolectados, procesados y analizados mediante el Análisis de Contenido. Resultados: la violencia doméstica vivida al inicio de las primeras relaciones afectivas comprometió seriamente la madurez emocional de la adolescente, lo que provocó el desarrollo de psicopatologías dejándola más vulnerable al uso y abuso de alcohol y otras drogas. Fue constatado también que la adolescente repitió su historia con su propia hija, reproduciendo el ciclo de la violencia. Conclusión: El embarazo durante la adolescencia, las experiencias de violencia doméstica y adicción a las drogas han potencializado la vulnerabilidad psicosocial de la adolescente.

\section{DESCRIPTORES}

Embarazo en la adolescencia

Violencia doméstica

Adicción a las drogas

\footnotetext{
${ }^{1} \mathrm{PhD}$ student in Clinical Psychology at the Institute of Psychology, University of Sao Paulo, Sao Paulo, Brazil. ${ }^{2}$ Master's degree in Clinical Psychology from the Institute of Psychology, University of Sao Paulo, Sao Paulo, Brazil. ${ }^{3}$ Master's student in Clinical Psychology at the Institute of Psychology, University of Sao Paulo, Sao Paulo, Brazil. ${ }^{4}$ Professor at the School of Psychology and Educational Sciences, University of Coimbra, and Researcher at the Center for Social Studies, University of Coimbra, Coimbra, Portugal. ${ }^{5}$ Associate Professor at the Institute of Psychology, University of Sao Paulo, Sao Paulo, Brazil. ${ }^{6}$ Professor in the undergraduate program in Obstetrics at the School of Arts, Sciences and Humanities, University of Sao Paulo, Sao Paulo, Brazil.
} 


\section{INTRODUCTION}

With the goal of obtaining in-depth research data, this article analyzes the case of a pregnant adolescent who is a victim of domestic violence and addicted to drugs ${ }^{(1)}$.

\section{Adolescent pregnancy}

Adolescent pregnancy is a high-risk pregnancy that has multiple possible repercussions in terms of psychosocial damage and maternal-fetal health. From the biological perspective, the most obvious risks are as follows: hemorrhage, prolonged labor, long-term complications, prematurity, intrapartum injury, perinatal death and low birth weight. From the psychosocial perspective, risks include dropping out of school, early entry into working life, imbalanced psychosocial integration and little preparation for the development of a satisfactory relationship with one's children ${ }^{(2)}$.

One study found that the population of adolescent mothers in Brazil decreased from 2001 to 2008. However, this percentage has increased considerably in families earning up to the minimum wage, which indicates a correlation between adolescent pregnancy and family income. This study also demonstrated that adolescent pregnancy affects the education level, particularly for those adolescent mothers who belong to the lowest social class (less than $30 \%)$, and concluded that dropping out of school and a lack of participation in the labor market are associated with both adolescent motherhood and the prior socioeconomic condition ${ }^{(3)}$.

Regarding the psychodynamic aspects of adolescent pregnancy, adolescent pregnancy and motherhood can be understood as difficulties in a girl's psychosexual development that resulting from unresolved childhood conflicts that impede the mourning of the losses of adolescence ${ }^{(4,5)}$.

Early pregnancy originates in an pre-Oedipal fixation, more specifically to the pre-Oedipal mother, as a result of deprivation and overstimulation. Adolescent pregnancy may be understood as an acting related to a girl's desire to take revenge on her mother because she feels rejected. In this sense, many adolescents become pregnant because they identify with the phallic mother (thus, the showing a pseudo-heterosexuality) ${ }^{(4)}$.

The relationship of adolescents with their parental figures may affect their object-choice. This study demonstrates how the mother's absence may hinder the establishment of new relationships. The emotional needs caused by this absence, which are expressed by high expectations and over-idealization, prevent the establishment of a relationship based on reality. Thus, frustrations with the real object are unavoidable, and the relationship becomes unsustainable ${ }^{(4)}$.

Thus, early pregnancy would be an acting related to an oral and pre-Oedipal fixation to the mother. When this girl is confronted with the demands of maturation uses the pregnancy as a way of to revive the mother-daughter bonding. In this context, at the level of fantasy fulfillment, the girl's sexual partner would correspond to the mother's place in the early relationship, and the sexual act and the subsequent fertilization would correspond to the reestablishment of an idealized mother-daughter bonding $(4,5)$.

In addition, the impulse to become pregnant does not originate in an $\mathrm{O}$ edipal desire to have a child or a model of assistant motherhood (as an assistant to the mother to care for the child), much less from a woman's desire to be a mother. It is more like a compulsive behavior, which may persist and tend to repeat itself. In this sense, there would be no use in controlling this phenomenon through instruction or birth control pills because of the nature of the acting ${ }^{(5)}$.

\section{Domestic violence}

Domestic violence is a problem that reaches far beyond Brazil. Several studies have revealed that violence against children and adolescents occurs worldwide in developed and developing countries ${ }^{(6-8)}$.

Research on the sex lives of adolescents who were maltreated before the age of 12 years found correlations between the experience of childhood maltreatment and early sexual initiation, sexual relationships established with multiple partners, the non-use of contraception and methods to prevent sexually transmitted diseases and adolescent pregnancy ${ }^{(9)}$.

Thus, child abuse (physical, sexual and emotional) becomes a risk factor for victims throughout life. Within the scope of physical health, those who were victimized tend to develop self-injurious behaviors, such as smoking, drinking, drug use and overeating, in addition to having greater difficulty with changing and maintaining healthier habits ${ }^{(10)}$.

Studies have also demonstrated the relationship between trauma (physical or sexual violence) and borderline personality disorder. In a study on 41 patients with borderline personality disorder, $76 \%$ of the patients reported being victims of sexual violence in childhood and $50 \%$ said that they had suffered continuous abuse ${ }^{(11)}$. Another study found that borderline patients significantly reported failures in maternal and paternal care during childhood, which indicates the importance of psychodynamic theories regarding the childhood of borderline patients and the theory of biparental failure in the development of this psychopathology ${ }^{(12)}$.

In Brazil, one study demonstrated that females are the primary victims of domestic and sexual violence: in $69.83 \%$ of the cases, domestic violence, sexual violence and other types of violence was directed against women ${ }^{(13)}$.

Domestic violence causes suffering because the abusive experience to which the child or adolescent was subjected causes a psychic imbalance, which cannot be repre-
Cumulative Vulnerability: A Case Study on Domestic Violence, Drug Addiction and Adolescent Pregnancy Miura PO, Passarini GMR, Ferreira LS, Paixão RAP, Tardivo LSLPC, Barrientos DMS 
sented or symbolized by the victim ${ }^{(14)}$. Another study also found that domestic violence is a risk factor for child and adolescent development, affecting identity, personality disorders and social adjustment ${ }^{(15)}$.

\section{Adolescent drug addition and pregnancy}

Young people, who long to establish an identity and face the anguish of not knowing "who they are", may identify with negative figures (e.g., criminals and drug addicts) or initiate a sexual life early as a manic defense organized to force the onset of an existential feeling and the sense or identify in order to control the strong feeling of "not being" (16). A study conducted with women dependent on crack cocaine demonstrated that users exposed to trauma during childhood or adolescence start using drugs at earlier ages than those whose trauma occurred in adulthood ${ }^{(17)}$.

Studies have indicated that factors such as dysfunctional families, truancy, unemployment and low professional training contribute to the maintenance of an unfavorable socioeconomic situation and to the high prevalence of cocaine and marijuana use by pregnant adolescents and those with psychiatric disorders ${ }^{(18,19)}$. Another study that corroborates these results found that the use of chemical substances, such as marijuana and alcohol, is correlated with the phenomenon of adolescent pregnancy because in many cases experience with drugs precedes adolescent pregnancy. Thus, these substances were used more frequently among adolescents who became pregnant than adolescents who did not become pregnant ${ }^{(20)}$.

Therefore, this article's purpose is to present and analyze the case of a pregnant adolescent who is a victim of domestic violence and addicted to drugs.

\section{METHOD}

This is a case study, which is an approach that should be used when "a) the questions 'how' and 'why' are proposed; b) the researcher has little control over events; c) the focus is on a contemporary phenomenon in the context of real life"(21). This same researcher states that this type of empirical research applies when the intent is to thoroughly understand a phenomenon that is currently occurring in real life, and whose understanding is linked to "important contextual conditions"(21). Thus, the case study serves to explain, describe, illustrate and examine highly complex situations that cannot be explained by simple cause-and-effect reasoning.

This study was conducted on a pregnant adolescent who sought treatment in the Obstetrics Emergency Unit (Pronto Atendimento - PA) at the Teaching Hospital of the University of São Paulo (Hospital Universitário da Universidade de São Paulo - HUUSP), which is located on the University of São Paulo (Universidade de São Paulo - USP) campus ${ }^{[1]}$. The instrument used was a semi-structured interview, which was recorded and transcribed, ensur- ing anonymity and confidentiality. The study respected the participant's privacy and intimacy and ensured her the freedom to participate in this process or to decline at any time, following the recommendations of the National Health Council according to resolution no. 466/2012.

The adolescent participant's legal guardian signed the consent form and the adolescent signed the assent form. All ethical precepts were followed, and the study was approved by the HUUSP Ethics Committee (Opinion no. 1214/12 and Record SISNEP-CAAE: 0043.0.196.198-11).

The data obtained in the semi-structured interview were interpreted and analyzed according to Content Anal$y$ sis ${ }^{[22]}$.

\section{RESULTS}

Taís $^{1}$ is 18 years old and pregnant. As a child, she was abandoned by her mother and father. Her mother is a drug user (crack cocaine) and lives on the streets. Taís was raised by her maternal grandmother, who is an alcoholic. The grandmother physically abused and was negligent with her granddaughter. The adolescent describes her life as one of suffering. She would prefer to live on the streets than in her grandmother's house because of the maltreatment she experiences at the hands of her grandmother.

Taís says that she married when she was 12 years old and separated from her husband when she was 16 . Soon after the separation, she met her current partner, Wagner (30 years old), who is the father of her unborn child. When Wagner was 24 , he suffered a spinal cord injury as a result of taking a "shot the wrong way", and he became a paraplegic. He was once a drug user. However, by the time Taís met him, he no longer used illicit drugs and only consumed alcohol. Taís thinks he is very "smart" and considers him to be a person who helps her when he can, talking with her and being welcoming to her.

Taís began to smoke marijuana when she was 15 years old, influenced by her ex-husband. At approximately 16, she began to use cocaine after being encouraged by a friend. Although she is unable to stop using drugs, she denies being addicted to them. For her, a drug addict is someone who begins to steal inside and outside the home to buy drugs, and because she does not have this attitude, she does not view herself as a drug addict.

Regarding her socioeconomic condition, Taís is a pregnant adolescent from a low social class. She dropped out of school during the $8^{\text {th }}$ grade and is not employed. She lives with her partner at his mother's house, where there are four adults (Taís, Wagner, the mother-in-law and a brother-in-law) living in three rooms. Only her motherin-law is employed. Her partner receives disability retirement payments.

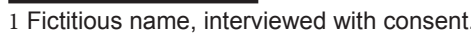




\section{DISCUSSION}

In this study, it was found that participants recognize the importance of health education for dengue prevention, since it enables a higher quality and effectiveness of actions. This perception is complemented by a study that described the influence of the educational process in the academic training, contributing to the formation of skills ${ }^{(11)}$.

The absence of health education teams in most counties in the state of Goiás, reported in the speeches, hinders the continuity of actions and the improvement of the educator-professional. Studies on the demands of health workers and the expectations about training at work, showed that permanent education provides a reflection on the reality of work, besides enabling the mobilization of workers and the perception of problems from the perspective of those involved ${ }^{(12,13)}$.

For the Committee representatives, the education in health expands the field of practice of the public health services management at the same time that it approximates management and the population, which allows the community to assume the responsibility for keeping the environment clean and free of breeding places of the mosquito that transmits dengue. A study demonstrated the importance of proximity between management and community in dengue control, by encouraging empowerment, as individuals empowered with knowledge have greater conditions to work together and become protagonists of their own lives ${ }^{(14)}$.

It was also evident that citizens who recognize their importance in disease prevention can develop their skills and become capable of coping with difficult situations. This perception of prevention was observed in all the speeches shown in this study, and should be inserted in the actions of permanent education of the surveyed institutions and services. A study found that for achieving improvements in the system for dengue surveillance in Brazil, the main suggestion of the Coordinators of the Center for Epidemiological Surveillance of the State of Goiás (54.5\%) and of the assistance professionals (43.8\%) was the training with focus on permanent education of the professionals involved in this surveillance. These surveyed professionals suggested the adequacy of human resources and infrastructure (40.9\%), and the assistance professionals suggested preventive actions $(25 \%)^{(15)}$.

It was emphasized by participants that investing in the prevention of dengue, which is a preventable disease, results in the rationalization of public health expenses and allows the redirection of investment to other diseases and disorders. The concern with costs generated by dengue is in agreement with some studies in which the costs of the dengue control program were evaluated ${ }^{(16,17)}$.

Team work was mentioned as a way to break the traditional vertical relationship between the health profession- al and the subject of the action, being a strategy to facilitate the collective and individual expression of the needs that influence health. Furthermore, it constitutes a tool for critical awareness of people. A study has shown that the educational process results in behavior change when the reciprocal group dialogue and the life experience of communities are taken into consideration ${ }^{(18)}$.

Intersectoriality was mentioned as a new guiding logic of public policies, especially to combat dengue, since it enables the articulation between knowledge and experiences. Moreover, it creates spaces where power relations are shared and individual interests are collectivized.

Studies have demonstrated the importance of coordinating external social spaces with the health sector, especially the school, which is a favorable environment for students learning to conquer their citizenship and form attitudes and values that lead them to behave intelligently ${ }^{(19-21)}$.

Finally, in this perspective of health education for prevention and control of dengue, the planning is necessary to decrease the risk of new epidemics, mainly by the potential of an epidemic during events involving many tourists $^{(22)}$. The surveillance allied to prevention educational activities in all the 553 micro areas of Brazil, point to the need of methodologies that should be done routinely for mass events like the World Cup, held in 2014, predicting the intersectoral organization for upcoming events, such as the Olympics to be held in Brazil in 2016 ${ }^{(23)}$.

\section{CONCLUSION}

This article demonstrates how the domestic violence experienced in early relationships eventually undermined the process of Taís's emotional development. She ended up developing severe psychopathological problems.

Adolescence is an intense and turbulent time and entirely depends on how each person experienced this process. In the case presented, Taís revives and resignifies her affective relationships based on previous experiences, i.e., based on mistrust, instability and maltreatment, which culminated in the abuse of licit and illicit drugs and adolescent pregnancy.

This recognition contributes nothing to the process of Taís's maturation. On the contrary, the adolescent is already displaying signs that she will repeat her own history with her daughter. Although she consciously does not want this repetition, her attitudes signal that it will occur.

Thus, domestic violence, drug abuse and early pregnancy act cumulatively as risk and vulnerability factors for the adolescent. They are a strong impediment to the healthy maturation of the adolescent and her baby and should be a key focus of research and preventive and interventive actions.
Cumulative Vulnerability: A Case Study on Domestic Violence, Drug Addiction and Adolescent Pregnancy Miura PO, Passarini GMR, Ferreira LS, Paixão RAP, Tardivo LSLPC, Barrientos DMS 


\section{Acknowledgments}

The authors thank the São Paulo Research Foundation (Fundação de Amparo à Pesquisa do Estado de São Paulo - FAPESP) for granting a post-doctorate scholarship to conduct this research and the Brazilian Federal Agency for Support and Evaluation of Graduate Education (Coordenação de Aperfeiçoamento de Pessoal de Nível Superior - CAPES) for granting a master's scholarship.

\section{REFERENCES}

1. Barrientos DMS. Estudo de violência doméstica contra adolescentes grávidas atendidas no Hospital Universitário de São Paulo: bases para intervenção [Study on domestic violence against pregnant adolescents treated at the University Hospital of São Paulo: Foundations for intervention]. Relatório Parcial Projeto de Pesquisa: Teste Piloto [Research Project Partial Report: Pilot Test]. Conselho Nacional de Desenvolvimento Científico e Tecnológico [National Council for Scientific and Technological Development], CNPq, Brazil. 2013.

2. Barbón Pérez OG. Algunas consideraciones sobre comunicación, gênero y prevención del embarazo adolescente [Some considerations on communication, gender and teen pregancy prevention]. Cienc. enferm. [online]. 2011;17(1):19-25. Available at: http://www.scielo.cl/pdf/cienf/v17n1/art 03.pdf

3. Novellino MSF. Um estudo sobre as mães adolescentes brasileiras [A study on adolescent mothers in Brazil]. Physis Revista de Saúde Coletiva. 2011;21(1):299-318.

4. Blos P. Adolescência. uma interpretação psicanalítica [On adolescence: A psychoanalytic interpretation]. 2a ed. São Paulo: Martins Fontes. 1998(1962).

5. Deutsch H. Problemas psicológicos da adolescência. com ênfase especial na formação de grupos [Selected problems of adolescence: With special emphasis on group formation]. 3a ed. Rio de Janeiro: Zahar. 1983(1967).

6. Finkelhor D, Ormrod R, Turner H, Hamby SL. The victimization of children and youth: a comprehensive national survey. Child Maltreatment. 2005;10(1):5-25.

7. Turner HA, Finkelhor D, Ormrod R, Hamby S, Leeb RT, Mercy JA, Holt M. Family context, victimization and child trauma symptoms: variations in safe, stable and nurturing relationships during early and middle childhood. American Journal of Orthopsychiatry. 2012;82(2):209-219.

8. Fontaine D, Nolin P. Personality disorders in a sample of parents accused of physical abuse or neglect. J. Fam. 2012;27:2331.

9. Black MM, Oberlander SE, Lewis T, Knight ED, Zolotor AJ, Litrownik AJ, Thompson R, Dubowitz H, English DE. Sexual intercourse among adolescents maltreated before age 12: a prospective investigation. Pediatrics. 2009;124(3):941-950.

10. Sachs-Ericsson N, Medley AN, Kendall-Tacknett K, Taylor J. Childhood abuse and current health problems among older adults: the mediating role of self-efficacy. Psychology of Violence. 2011;1(2):106-120.

11. Silk K, Lee S, Hill E, Hohr N. Borderline personality disorder symptoms and severity of sexual abuse. The American Journal of Psychiatry. 1995;152 (7):1059-1064.

12. Hallie Z, Paris J. Parents emotional neglect and overprotection according to the recollections of patients with borderline personality disorder. American Journal of Psychiatry. 1991;148:648-651.

13. Brasil. Ministério da Saúde [Ministry of Health]. Sistema de Vigilância de Violência e Acidentes [Surveillance System for Violence and Accidents]. [Internet]. Brasília; 2011. [cited September 29, 2013]. Available at <http://portalsaude. saude.gov.br/portalsaude/arquivos/pdf/2013/Mar/22/viva 2011.pdf $>$

14. Pinto Jr AA, Vieira FC, Santos MR, Fróis NMR, Tardivo LSLPC. Vitimização e Violência: Atendimentos clínicos a partir de enquadres diferenciados [Victimization and Violence: Clinical consultations using different frames]. In: Tardivo LSLPC, Gil CA. (Orgs.). Apoiar: novas propostas em psicologia clínica [Support: new proposals in clinical psychology]. São Paulo: Savier; 2008. p.513-22.

15. PintoJr AA, Tardivo LSLPC. IFVD: Inventário de frases no diagnóstico de violência doméstica contra crianças e adolescentes [PIDV: Phrase inventory for diagnosing domestic violence against children and adolescents]. São Paulo: Vetor; 2010.

16. Knobel M. A síndrome normal da adolescência [The normal syndrome of adolescence]. In: Aberastury A, Knobel M. (Org.) Adolescência normal: um enfoque psicanalítico [Normal adolescence: A psychoanalytical focus]. Alegre: Artmed; 2011(1970). p.24-62.

17. Tractenberg SG, Viola TW, Rosa CSO, Donati JM, Francke LD’A, Pezzi JC, Grassi-Oliveira R. Exposição a trauma e transtorno de estresse pós-traumático em usuárias de crack [Trauma exposure and post-traumatic stress disorder in crack cocaine users]. J Bras Psiquiatr. 2012;61(4):206-13. 
18. Mitsuhiro SS, Chalem E, Barros MM, Guinsburg R, Laranjeira R. Teenage pregnancy: use of drugs in the third trimester and prevalence of psychiatric disorders. Rev Bras Psiquiatr. 2006;28(2):122-5.

19. Barnes M, Ismail KMK, Crome LB. Triply troubled: criminal behaviour and mental health in a cohort of teenage pregnant substance misusers in treatment. Criminal Behaviour and Mental Health. 2010;20:335-48.

20. Cavazos-Rehg PA, Krauss MJ, Spitznagel EL, Schootman M, Cottler LB, Bierut LJ. Brief report: pregnant by age 15 years and substance use initiation among US adolescent girls. Journal of Adolescence. 2012;35:1393-97.

21. Yin RK. Estudo de Caso [Case Study Research]. Planejamento e métodos [Design and methods]. 4a ed. Porto Alegre: Bookman; 2009.

22. Bardin L. Análise de Conteúdo [Content Analysis]. Lisboa, Portugal: Edições 70; 2013.

23. Winnicott DW. Da dependência à independência no desenvolvimento do indivíduo [From dependence towards independence in the development of the individual]. In: Winnicott DW. O ambiente e os processos de maturação [The maturational processes and the facilitating environment]. Porto Alegre: Artes Médicas; 1990(1963). p.79-87.

24. Winnicott DW. A integração do ego no desenvolvimento da criança [Ego integration in child development]. In: Winnicott DW. O ambiente e os processos de maturação [The maturational processes and the facilitating environment]. Porto Alegre: Artes Médicas; 1990(1962). p.55-61.
25. Winnicott DW. Distorção do ego em termos de falso e verdadeiro self [Ego distortion in terms of true and false self]. In: Winnicott DW. O ambiente e os processos de maturação [The maturational processes and the facilitating environment]. Porto Alegre: Artes Médicas; 1990(1960). p.128-39.

26. Winnicott DW. A imaturidade do adolescente [Adolescent immaturity]. In: Winnicott DW. Tudo começa em casa [Home is where we start from]. São Paulo. Martins Fontes; 2005(1968). p.145-63.

27. Figueiredo LC. Psicanálise: elementos para a clínica contemporânea [Psychoanalysis: Elements for the contemporary clinic]. São Paulo: Escuta; 2008.

28. Winnicott DW. A criatividade e suas origens [Creativity and its origins]. In: DW Winnicott. O brincar e a realidade [Playing and reality]. Rio de Janeiro: Imago; 1975(1971). p.95-120.

29. American Psychiatric Association. Diagnostic and Statistical Manual of Mental Disorders, Fifth Edition. Arlington VA: American Psychiatric Association; 2013.

30. Kernberg O. Borderline conditions and pathological narcissism. New York: Jason Aronson; 1976. 